\title{
Relationship between Perceived Organizational Support and Organizational Affective Commitment: Moderating Role of Psychological Contract Breach
}

Widya Andini ${ }^{\mathrm{a}}$ and Endang Parahyanti ${ }^{\mathrm{b}}$

${ }^{a}$ Faculty of Psychology, Universitas Indonesia, Depok, Indonesia; ${ }^{b}$ Department of Industrial and Organizational Psychology, Faculty of Psychology, Universitas Indonesia, Depok, Indonesia

*Corresponding author:

Endang Parahyanti

Department of Industrial and Organizational Psychology

Faculty of Psychology, Universitas Indonesia

Depok, Jawa Barat, Indonesia

Email address: parahyanti@gmail.com 


\title{
Relationship between Perceived Organizational Support and Organizational Affective Commitment: Moderating Role of Psychological Contract Breach
}

\begin{abstract}
Currently, the workforce is dominated by generation $\mathrm{X}$ and generation $\mathrm{Y}$. Generation $\mathrm{Y}$ or the millennial generation will dominate the workforce in the next few years. Changes in the social environment can exert an impact on the changing value systems that exist in each generation. Such modifications cause different characteristics to emerge among generations, especially in the workplace. The present issue pertaining to employees belonging to the millennial generation concerns their problems about remaining in a company for extended periods. The decision to stay with a company implies an organizational commitment and the millennials exhibit a lower level of loyalty to a single company than employees belonging to the previous generation. Existing studies elucidate that the perception of support from the organization is a factor that increases employee commitment, especially in the affective aspect. This study aims to explore whether the affective commitment of millennial employees is still influenced by the perception of organizational support (POS) and to ascertain whether the psychological contract breach (PCB) plays a role in moderating this relationship. Using the convenience sampling method, questionnaires were disseminated online and offline to millennial employees aged between 22 and 35. The obtained results revealed that POS was significantly correlated with affective commitment while the PCB displayed an insignificant moderating role in the relationship between POS and affective commitment in millennial employees. This outcome clarified that the level of affective commitment increases if millennials perceive the organization support to be higher. Further, the organization must also understand the manner in which to strengthen this relationship by considering the different needs of the millennial generation of employees.
\end{abstract}

Keywords: affective commitment, millennial employees, perceive organizational support, psychological contract breach

\section{Introduction}

Employees form one of the most important resources of a company. An enterprise's employees can be distinguished by their generation and currently, workplaces are dominated by people born between 1982 and 2000, belonging to the X and Y generations. The Y generation, also known as the millennials, comprise the youngest workers and in the next few years, this generation will dominate the workforce across the world (Kultalahti \& Liisa Viitala, 2014). Based on statistical data as of February 2018, 34.15\% of Indonesian workers are aged between 20 and 34 years (bps.go.id).

One of the many challenges faced by a company's managers concerns the varying characteristics of the employees of the organization. Nowadays, the differences do not merely pertain to the 
religious, gender, ethnic, and racial backgrounds of the workers but also to the discrete generational values (Gibson, Greenwood \& Murphy, 2009). Kultalahti and Liisa Viitala (2014) have explained that transformations in the social environment can exert an impact on the changing value systems that exist in each generation. Such differences can affect employees' values and beliefs about the work, the organization, the work goals, the expectations from work life, and the work ethics. Thus, managers must understand the differences between these two generations, because errors in understanding these inter-generational variations can affect employee performance and satisfaction at work (Smith \& Nichols, 2015). It is also vital for a manager or an organization to know how to motivate and satisfy millennial employees so that they may be attracted to the company and retained within its workforce (Smith \& Nichols, 2015).

Gibson et al. (2009) confirmed the basic disparities between three generations in the workplace: the baby boomers, generation $\mathrm{X}$, and the millennials. The results of this study revealed that the baby boomer employee works hard, is resistant to authority, and feels the right to be in charge has been earned. In the workplace, generation $\mathrm{X}$ employees value family-work balance more than the other generations and are not particularly loyal to their employers. As a generation, on the other hand, millennial employees are characterized as being familiar with technology, socially networked, constantly connected, and needing instant gratification in the workplace. Another research initiative by Kultalahti and Liisa Viitala (2014) reported several differences between millennials and the previous generation; millennials were found to be familiar with technology, socially active, comfortable with change, willing to develop their abilities, and looking for new workplace challenges.

The millennial generation is also known to easily move from one company to another. Suryaratri, Abadi, and Jakarta (2018) detailed the results of a survey conducted by PT. Unilever in Indonesia stating that 60 percent of young workers move to another company in one to three years. The results of another survey conducted by JobStreet.com on 3500 respondents in Indonesia also evidenced that 65.6 percent millennials did not feel comfortable working in a single company for a long time and changed jobs in less than a year (Suryaratri et al., 2018).

Wang, Wang, Xu, and Ji, (2014) clarified that employee turnover is a negative influence on a business enterprise. Attrition can cause direct effects such as increasing in labor costs, and can indirectly impact an organization via the loss of intangible assets and reduction of the company's competitive advantages. Another study by Surji (2013) elucidated certain cost impacts of turnover caused by the downtime, recruiting, interviewing, orientation, training, and the rampup time. Further, turnover can affect customer service and quality, result in the lack of employee motivation and low morale, and affects the magnitude of valuable motivational factors.

According to Allen and Meyer (1996) the decision to stay on in a company is a manifestation of organizational commitment. A study by Yuen (2018) revealed that employees belonging to the millennial generation evince lower levels of job satisfaction in comparison to the previous generation. Organizational commitment may be defined as a psychological relationship between employees and the organization where they work so that the employee is less likely to 
voluntarily quit the company (Allen \& Meyer, 1996). Employees and their organizations exhibit three different types of relationships. First, workers with strong affective commitment exhibit their desire to remain in the organization. Personnel with this form of commitment identify with the company, become involved in its goals, and are emotionally attached to the organization. The second form may be labeled continuance commitment. Employees with this form of commitment stay in the organization because of the identification of the costs they would be likely to incur if they left the organization. Thus, such employees are compelled to remain in the organization. Third, some workers have normative commitment to their company. Such employees feel a sense of obligation to the organization which makes them remain (Allen \& Meyer, 1996). Setyasih (2016) elaborates that affective commitment is the true form of loyalty to an organization because employees with this kind of commitment would always want to be part of the organization and would accept the organization's vision their own. Hence, the focus of this study is to ascertain the affective commitment of millennial employees.

Mowday et al. (1991) noted four antecedents of affective commitment. The first pertains to personal characteristics such as demographic features (age, tenure, sex, and education), personal dispositions (need for achievement, affiliation, and autonomy), and interaction with the environment. The second involves organizational structure and includes the decentralization of decision making and the formalization of policy and procedure. The third and fourth precursors are job characteristics and the subjective work experiences of workers. These aspects may be explained using the more global term, work experience. Work experience that fulfills the needs of employees or fits with their values tends to foster affective commitment. There are two categories of work experience: factors that satisfy an employee's need to feel comfortable in the organization, and attributes that contribute to a worker's sense of competence at the job that is performed.

Some extant investigations have attempted to determine the specific expectations of millennial employees from their jobs. Guillot and Soulez (2014) concluded that the millennial employee sought a positive work environment, a supportive culture, and a collective management style. They also reported that generation $\mathrm{Y}$ workers prefer to select jobs that offer opportunities for advancement and long-term career progression. These expectations may help to explain why millennial employees are more attracted to organizations that invest in training and development. Another Study by Kultalahti and Liisa Viitala (2014) also asserted that work-life balance is a very critical factor for the millennial generation, followed by motivated and engaged colleagues, and varying and interesting tasks.

\section{Theoretical Background}

\section{Perceived Organizational Support and Affective Commitment}

Organizational commitment is described as the psychological relationship between an employee and the organization so that the employee is less likely to voluntarily leave the company (Allen \& Meyer, 1996). Work experience combines two antecedents of affective commitment (Meyer \& Allen, 1991). A previous study by Rhoades, Eisenberger, and Armeli (2001) found that perceived organizational support mediated the relationship between work experience and 
affective commitment. According to their investigation, POS was reinforced by favorable work experiences through decisions that were voluntarily and purposefully made by the organization. In other words, the relationship between POS and favorable work experiences was stronger when those experiences were associated with organizational policy.

Rhoades and Eisenberger (2002) elucidated that perceived organizational support is defined as an employee's perception of the extent to which the organization values their contribution and the degree of the organization's caring about their well-being. Employees who perceived support from the organization tend to respond with increased loyalty, commitment, and performance. Lee and Jeung (2018) clarified that the relationship between POS and affective commitment should be discussed in the context of the social exchange theory. When employees perceive an organization's support, they are likely to reciprocate the favorable treatment and to expect that their efforts will lead to greater rewards or will fulfill their socio-emotional needs. This belief causes increased affective commitment. Another study by Eisenberger, Armeli, Rexwinkel, Lynch, and Rhoades (2001) proved that the relationship between POS and affective commitment is mediated by a sense of obligation. Their investigation revealed that POS makes employees feel responsible for the organization's welfare and makes them want to help the organization achieve its objectives.

Pursuant to the above review, this study attempted to ascertain whether perceived organizational support influences affective commitment in millennial employees. The authors hypothesize:

$\mathrm{H}_{1}$ : There is significant correlation between perceived organizational support and the feeling of affective commitment in millennial employees

\section{Psychological Contract Breach as a Moderating Factor in the Relationship between Perceived Organizational Control and Affective Commitment}

Lind and Tyler (in Gupta, Agarwal, \& Khatri, 2016) explained that organization resources are not, by themselves, sufficient to shape employee's attitudes and behavior towards the organization. This resources' magnitude can be defined by the employee evaluation about the fulfilment of expectation that already promised by the organization (Gupta, Agarwal \& Khatri, 2016). Employee's cognitive evaluations regarding the extent of fulfilment of the promised obligations is referred to as "psychological contract" (Gupta et al., 2016). Robinson and Wolfe Morrison (2000) explain that psychological contract breach can occur owing to three factors: reneging; incongruence; and, vigilance. Reneging happens when someone or a group within the organization realize that there $i s$ an obligation, but also realize that they can't meet that obligation. Incongruence happens when employees and organizations have a different understanding of the obligations that have to be fulfilled by the organization. The last factor, vigilance, refers to how far the employee actively monitors the organization in executing the contractual agreement. Employees also tend to perceive that their psychological contract has been breached when: the organization performs poorly; when they receive a report about their own low performance; when they didn't undergo formal process of socialization; and, when they had less interaction with members of the organization before being hired (Robinson \& Wolfe Morrison, 2000). A study by Lapointe, Vandenberghe, and Boudrias (2013) explained that 
psychological contract breach can be explained as a stressor which changes the quality of relationship between employee and organization and depletes organization-related resources relating to employees. This situation could lead to the tendency to think about leaving the organization and also the experience of emotional exhaustion.

According to previous explanations, Agarwal and Khatri (2016) explained that the magnitude of effects of organizational resources on employee outcomes, e.g., affective commitment, depends on the employee's evaluation of organizational fairness regarding the fulfillment of expectations which have already been promised by the organization. The result from this study also showed that interaction between POS and psychological contract breach were significant in predicting affective commitment. A study by Islam, Khan, Khawaja, and Ahmad (2017) also noted that the perception of psychological contract breach could make psychological bonds between employees and the organization weaker. This breach of the psychological contract increases the stress levels and makes them believe that their organization does not care about their personal values. Such are situation could affect their emotional attachment.

Based on these explanations, we would like to examine further the moderating role of psychological contract breach in relationships between perceived organizational control and affective commitment, especially with reference to millennial employees. Hence, the second hypothesis is:

$\mathrm{H}_{2}$ : there is a significant role of Psychological contract breach acting as moderation in the relationship between perceived organizational support and affective commitment.

\section{Methods}

\section{Participants and Procedure}

This study aims to uncover factors that can retain employees, especially millennial employees, within an organization. Therefore, the participants in this study are employees who are of the millennial generation. According to Kultalahti and Liisa Viitala (2014), the millennial generation, otherwise known as generation Y, was born between 1982 until 2000. Samples were taken with a convenience sampling technique which was distributed by online and offline questionnaires to the millennial employees.

Total participant numbers in this study were 94 millennial employees, consisting of $37 \%$ men and $63 \%$ women. The age range of participants in this study was from 22 to 35 years old $(\mathrm{M}=$ 26.06, SD = 2.38). Participants worked in companies in several cities in Indonesia- $86 \%$ in Jabodetabek, $14 \%$ outside Jabodetabek. Participants were employees who worked in BUMN $(5 \%)$, government $(32 \%)$, and private $(63 \%)$ institutions.

\section{Measurement}

Three questionnaires measured each variable in this study. POS is measured using a questionnaire from Rhoades \& Eisenberger that has been adapted to Bahasa Indonesia (Indonesian) by Widiya (2012), and with a reliability value of .904. This questionnaire consists 
of 18 items. Samples of items are: 'Pekerjaan dan peran yang diberikan membuat saya merasa bahwa perusahaan memberikan sedikit kesempatan untuk promosi' (reversed item) and 'Pekerjaan dan peran yang diberikan membuat saya merasa bahwa perusahaan Peduli terhadap kepuasan kerja saya secara keseluruhan'. Participants were asked to respond to each item on a 6 point Likert scale, 1 for "very disagreed" and 6 for "very agreed".

Psychological contract breach is measured using a global scale developed by Robinson and Morrison that measured employees' perception about how well the organizations had fulfilled their employees' psychological contracts. This questionnaire has been adapted to Bahasa by Fiftina (2014), and has a reliability value of .76. This questionnaire consists of 6 statements measured by 6 Likert scales. The sample of items are: 'Perusahaan tidak berusaha memenuhi janjinya kepada saya' and 'Perusahaan telah memenuhi hampir semua janji yang dibuat saat perekrutan.' (reversed item)

The last variable is affective commitment, which is measured using the Affective Commitment Scale (ACS) developed by Meyer and Allen and has been adapted to Bahasa Indonesia (Indonesian) by Ersya (2016) with a reliability value of .673. This questionnaire consists of six statements measured using a 7 point of Likert scale, 1 indicating "strongly disagree" and 7 showing "strongly agree". Samples of items from this scale are: 'Saya merasa senang untuk menghabiskan sisa karier saya bersama perusahaan ini' and 'Saya tidak merasa memiliki dan menjadi bagian dari organisasi ini' for reversed item.

\section{Data Analysis}

All data was collected and scored from all participants. Statistical analysis in this study is done through regression analysis using SPSS and moderation analysis using PROCESS for SPSS from Hayes (2013).

\section{Results and Discussion}

Results of mean, standard deviation, correlation, and reliability of each of the variables in this study are showed in Table 1 . These measurements are done by calculating the average of the three variables. Data processing was performed using SPSS descriptive analysis and Pearson's correlation. The results of these calculations show that POS has positive relationship with affective commitment, or that a higher score on POS will give higher score on affective commitment. PCB has negative relationship with other variables. 
Table I. Mean, Standard Deviation, Correlation and Reliability of Variables

\begin{tabular}{|l|l|l|l|l|l|l|l|}
\hline & M & SD & $\mathbf{1}$ & $\mathbf{2}$ & $\mathbf{3}$ & $\mathbf{4}$ & $\mathbf{5}$ \\
\hline 1. Sex & 1.64 & .48 & & & & & \\
\hline 2. Age & 26.06 & 2.38 & $-.24^{*}$ & & & & \\
\hline 3. POS & 71.88 & 12.48 & -.10 & $.20^{*}$ & $(.904)$ & & \\
\hline 4. PCB & 17.93 & 5.72 & -.08 & -.15 & $-.61^{* *}$ & $(.76)$ & \\
\hline 5. AC & 27.35 & 6.46 & -.06 & $.24^{*}$ & $.64^{* *}$ & $-.32^{* *}$ & $(.673)$ \\
\hline
\end{tabular}

Note: POS (Perceived Organizational Support), PCB (Psychological Contract Breach), AC (Affective Commitment). $* \mathrm{p}<0.05, * * \mathrm{p}<0.01$.

The results of the analysis showed that POS significantly affected the affective commitment of millennial employees $\left(\mathrm{R}^{2}=.415, \mathrm{p}<.001\right)$. This result shows that $41.5 \%$ of the variance in affective commitment can be explained by POS. A coefficient value of 0.33 indicates that each 1 unit increase in POS will increase 0.33 units in the value of affective commitment.

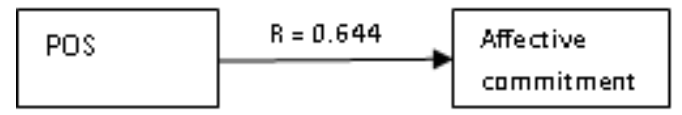

Fig. 1. Correlation between POS and Affective Commitment

Based on the results of calculations performed, it can be seen that there is significant relationship between POS and affective commitment on millennial employees. This relationship can be explained by several previous studies which also support the results of this study. Organizational support theory explains that POS relations and affective commitment are based social exchange, and the overall social enhancement process (Lee \& Jeung, 2018). Rhoades et al. (2001) explain that, based on reciprocity norms, POS make employees feel responsible for, and caring about, the organization's welfare and therefore helping the organization reach its objectives. This causes employees to feel that they could fulfill their obligations through affective commitment and their efforts to help the organization. In addition, POS can also increase affective commitment by meeting employees' needs for appreciation, agreement and affiliation so that they can direct employees to organizational membership and channel role status into their social identity (2001). Kurtessis, et al. (2017) explained that POS can increase identification with organizations by enabling them to meet socio-emotional needs and thereby, potentially, increase affective commitment.

The next analysis was aimed at examining whether PCB moderates the relationship between POS and the affective commitment of millennial employees. The results of the analysis showed that PCB does not have a significant moderator role in the relationship between POS and affective commitment, $B=-.0043, \mathrm{t}(90)=0.655, \mathrm{p}=0.5141$. In other words, the influence of POS on organizational commitment is not influenced by the level of PCB owned by millennial employees. 


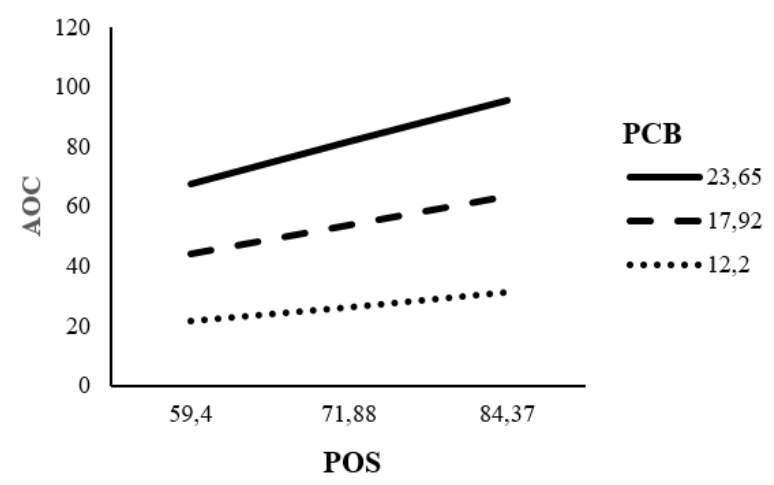

Fig. 2. Moderation effect of Psychological Contract Breach on relationship between POS and Affective Commitment

The second result of this study showed that there is an insignificant moderator role of PCB on the relationship between POS relations and affective commitment of millennial employees. Robinson and Morrison (2014) describe PCB perceptions as a cognitive process by employees utilised to compare what they actually get in comparison with what the organization had/has promised. Contextual hypothesis explained that psychological contract expectations, which could lead to PCB in millennials, are determined by employees' socioeconomic context (De Hauw \& de Vous, 2010). In their study, socioeconomic context influences how millennials respond when the organization fails to fulfill their expectations. Consequently, psychological contract breach generates a smaller effect upon outcome variables with millennials (De Hauw $\&$ de Vous, 2010). Another study also explained that perception of psychological contract breach also depended on several factors, such as how close the employee is monitoring the organization in terms of it executing the contractual agreement, or how many job alternatives they may have (Robinson \& Wolfe Morrison, 2000).

Another study by Moore (2014) also explained that age has an impact upon psychological contract. As concluded from his literature review, age can affect the employee's flexibility surrounding psychological contract perception, and millennials have lower perception about obligations that need to be fulfilled by the organization than other generational groups (Moore, 2014).

\section{Conclusion}

From the analysis performed in this study, we can conclude that Perceived Organizational Support influences affective commitment in millennial employees. In other words, one of the preferences of millennial employees in a company is the extent to which companies where they work value their particular contribution and care for their individual well being

The second result of this study shows that the role of PCB is not significant as a moderator in the relationship between POS and affective commitment. This shows that PCB factors do not have a significant influence on millennial employees. Based on these results, the company can provide other offers to increase motivation and retain employees, especially millennial employees. 


\section{Implications}

\section{Theoretical Implications}

The results of this study could have an impact on literature dealing with millennial employees in the workplace, especially in Indonesia. The first result of this study has enriched the social exchange theory which explained how millennial employees' perception about their organizational support correlates with their affective commitment. From the second result of this study, we can understand more clearly that differences between the millennial generation and older generations can generate different responses regarding psychological contract and thereby affect their affective commitment(s) differently.

\section{Practical Implications}

In practice, companies need to understand the motivation and needs of their employees. In dealing with employee demands which will come to be dominated by the millennial generation, it is important to understand things that can increase millennial employee commitment. The results of this study indicate that millennial employee commitment can be influenced by the appreciation given by the organization regarding the contributions that have been given by these employees. Lutfiyati (1989) explains that there are three factors that can improve employee's perception of organizational support. The first factor is the perception of procedural fairness, which includes the method used in determining the distribution of resources among employees. The second factor is perception of appreciation and working conditions such as appreciation, recognition, salary, promotion, job security, autonomy, role stressors and training. Besides that, the role of supervisors can also be a factor in improving POS, so the third factor is the perception of support from supervisors. This is because supervisors can also act as agents of the organization, so that employees' perceptions of their supervisors are one of the key indicators of organizational support as perceived by its employees.

Besides giving support to its employees, the organization also needs to know and understand factors that can strengthen the relationship between organizational support and affective commitment, especially for millennial employees. This can be done by knowing what preferences are considered important by millennial employees in choosing an organization. Research by Guillot and Soulez (2014) explained three key attributes which have become central for millennial employees, namely: type of contract; atmosphere at work; and, distance from home. In their study, Gibson et al. (2009) stated that millennial employees want attention and feedback. Managers should try to make work more exciting and relevant for millennial employees, but also be careful to show them verifiable career opportunities.

\section{Recommendation}

Based on this study, there are several indications for further research. One of the limitations of this study is the number of participants, and also the diversity of participants. Further research can be carried out with more participants and with more varied types of work in order to describe the millennial employees in Indonesia as a whole. In addition, several previous studies have proven that affective commitment affects the turnover rate of employees. Hence, further 
research is needed as to whether the affective commitment also affects the turnover rate of millennial employees.

\section{References}

Allen, N. J., \& Meyer, J. P. (1996). Affective, continuance, and normative commitment to the organization: An examination of construct validity. Journal of Vocational Behavior, 49(3), 252-276. doi: 10.1006/jvbe.1996.0043. PubMed: 8980084.

De Hauw, S., \& de Vos, A. (2010). Millennials' career perspective and psychological contract expectations: Does the recession lead to lowered expectations? Journal of Business and Psychology, 25(2), 293-302. doi: 10.1007/s10869-010-9162-9.

Eisenberger, R., Armeli, S., Rexwinkel, B., Lynch, P. D., \& Rhoades, L. (2001). Reciprocation of perceived organizational support. Journal of applied psychology, 86(1), 42-51. doi: 10.1037/0021-9010.86.1.42. PubMed: 11302232.

Ersya, C. H. A. I. (2016). The influence of general self efficacy and organizational mobility preferences toward affective commitment (Unpublished undergraduate mini thesis). Universitas Indonesia, Depok.

Fiftina, A. F. (2014). The relationship between psychological contract breach and psychological empowerment with innovative behavior (Master thesis). Universitas Indonesia, Depok.

Gibson, J. W., Greenwood, R. A., \& Murphy Jr, E. F. (2009). Generational differences in the workplace: Personal values, behaviors, and popular beliefs. Journal of Diversity Management (JDM), 4(3), 1-8.

Guillot-Soulez, C., \& Soulez, S. (2014). On the heterogeneity of Generation Y job preferences. Employee Relations, 36(4), 319-332. doi: 10.1108/ER-07-2013-0073.

Gupta, V., Agarwal, U. A., \& Khatri, N. (2016). The relationships between perceived organizational support, affective commitment, psychological contract breach, organizational citizenship behaviour and work engagement. Journal of advanced nursing, 72(11), 2806-2817.

Islam, T., Khan, M. M., Khawaja, F. N., \& Ahmad, Z. (2017). Nurses' reciprocation of perceived organizational support: the moderating role of psychological contract breach. International Journal of Human Rights in Healthcare, 10(2), 123-131.

Kultalahti, S., \& Liisa Viitala, R. (2014). Sufficient challenges and a weekend ahead-Generation Y describing motivation at work. Journal of Organizational Change Management, 27(4), 569-582.

Kurtessis, J. N., Eisenberger, R., Ford, M. T., Buffardi, L. C., Stewart, K. A., \& Adis, C. S. (2017). Perceived organizational support: A meta-analytic evaluation of organizational support theory. Journal of management, 43(6), 1854-1884.

Lapointe, É., Vandenberghe, C., \& Boudrias, J. S. (2013). Psychological contract breach, affective commitment to organization and supervisor, and newcomer adjustment: A three-wave moderated mediation model. Journal of Vocational Behavior, 83(3), 528-538.

Lee, J. W., \& Jeung, C. W. (2018). Employee Status and the Consequences of Perceived Organizational Support. Journal of Personnel Psychology, 17(2), 75-82.

Lutfiyati, E. (1989). Improving perceived organizational support and work engagement among gen $x$ 's and $y^{\prime} s$ at $L K N$ B by $3 R$ training intervention (Master thesis). Universitas Indonesia, Depok.

Meyer, J. P., \& Allen, N. J. (1991). A three-component conceptualization of organizational commitment. Human resource management review, $1(1), 61-89$.

Moore, T. (2014). The Impact of Psychological Contract Fulfillment on Employee Engagement in the Millennial Generation: The Moderating Effects of Generational Affiliation (Doctoral dissertation). Georgia State University, Atlanta.

Pamungkas, C. A. (2012). Differences of transactional psychological contract relational, and psychological contract breach between permanent and temporary employees (Undergraduate mini thesis). Universitas Indonesia, Depok.

Rhoades, L., \& Eisenberger, R. (2002). Perceived organizational support: A review of the literature. Journal of Applied Psychology, 87(4), 698-714. doi: 10.1037/0021-9010.87.4.698. PubMed: 12184574. 
Rhoades, L., Eisenberger, R., \& Armeli, S. (2001). Affective commitment to the organization: the contribution of perceived organizational support. Journal of Applied Psychology, 86(5), 825-836. doi: 10.1037/00219010.86.5.825. PubMed: 11596800

Robinson, S. L., \& Wolfe Morrison, E. W. (2000). The development of psychological contract breach and violation: A longitudinal study. Journal of Organizational Behavior, 21(5), 525-546.

Setyasih, N. (2016). Organizational commitment of sensation seeker the role of mastery to re-expressed sensation seeking (Master thesis). Universitas Indonesia, Depok.

Smith, T. J., \& Nichols, T. (2015). Understanding the millennial generation. The Journal of Business Diversity, $15(1), 39$.

Surji, K. (2013). The negative effect and consequences of employee turnover and retention on the organization and its staff. European Journal of Business and Management, 5(25), 52-65.

Suryaratr, R. D., \& Abadi, M. A. (2018). Modal Psikologis dan Intensi Job Hopping pada Pekerja Generasi Millenial. IKRA-ITH HUMANIORA: Jurnal Sosial dan Humaniora, 2(1), 77-83.

Wang, X., Wang, L., Xu, X., \& Ji, P. (2014). Identifying employee turnover risks using modified quality function deployment. Systems Research and Behavioral Science, 31(3), 398-404.

Widiya, Y. A. (2012). Coaching Training on Supervisor to Increase Perceived Organizational Support and Reduce Turnover Intention of Employees at AI Company (Master thesis). Universitas Indonesia, Depok. 